\title{
Effect of Company Age, Size of Public Accounting Firm and Firm Solvency on Audit Delay
}

\author{
Oktariansyah $^{1}$, Andri Eko Putra ${ }^{2}$ and Henny Karunia Putri ${ }^{3}$ \\ Economic Faculty, PGRI Palembang University, INDONESIA ${ }^{1,2,3}$
}

\begin{tabular}{l}
\hline \hline ARTICLE INFO \\
\hline \hline Article history: \\
Received: August 18, 2021 \\
Revised: Feb 9, 2022 \\
Accepted: Feb 21, 2022 \\
\hline Keywords: \\
Audit Delay; Company \\
Age; Public Accounting \\
Firm Size; Company \\
Solvency \\
\hline Correspondence: \\
Henny Karunia Putri \\
putrihenny96@gmail.com
\end{tabular}

\begin{tabular}{l}
\hline \hline ABSTRACT \\
\hline \hline This research aims to determine the impact of firm age, Size of Public \\
Accounting Firm (PAF size), and firm solvency on audit delay. The population \\
in this study is the financial statements of mining companies listed on the \\
Indonesia Stock Exchange (IDX) audited for the $2017-2019$ period. The study \\
incorporated a quantitative research design. The samples used in this study \\
were 32 companies with four years of observation, so a sample of 96 was \\
obtained using the purposive sampling method. The data analysis technique \\
used is multiple linear regression through SPSS version 21. Audit Delay is \\
affected by Company Age, Audit Delay is affected by the PAF Size, Audit \\
Delay is not affected by Company Solvency, and There is an effect of Company \\
Age, size of the Public Accounting Firm and firm solvency on Audit Delay
\end{tabular}

How to cite (APA Style):

Oktariansyah, Putra, A.E., Putri, H. K. (2022). Effect of Company Age, Size of Public Accounting Firm and Firm Solvency on Audit Delay. Jurnal Akuntansi, 12 (1), 63-72. https://doi.org/10.33369/j.akuntansi.12.1.63-72

\section{INTRODUCTION}

Many companies have gone public, so a lot of auditing of financial statements is needed. Financial statements are an important source of information about an issuer used by interested parties to base investment decisions. The information provided must be relevant and reliable. It means that the information is obtained quickly. Time efficiency in preparing/presenting financial reports can impact the quality of financial statement information.

The challenge for issuers when publishing financial reports to the public and the Capital Market Supervisory Agency (BAPEPAM) is the efficiency in completing reports that public accountants have audited. Issuer's Annual Report Based on the Decision of the Head of BAPEPAM and LK No: KEP-431/BL/2012 states that issuers who are members of the IDX report mandatory annual financial reports to BAPEPAM and LK. The time set is no later than 120 days when the book closes.

The company's age is the operation of an issuer. Public Accounting Firm is an institution authorized by the Minister of Finance to carry out work as an auditor. The PAF's Size is divided into four major PAFs and four non-big PAFs. Solvency is the condition of the company's debt, both short/long term. Audit delay is the time from the closing date of the company's books to the date of the audit report issued. There are two factors that affect audit delay, namely internal and external factors. For example, the internal factors are the company's size, company's age, solvency, and profitability, while examples of external factors are the PAF Size and the type of audit opinion (Harjanto, 2017).

Issuers that were late in reporting their 2017 financial statements in 2018 were 17 in number, consisting of mining companies, namely PT Garda Tujuh Buana Tbk, PT Apexindo Pratama Duta Tbk, PT Astrindo Nusantara Infrastruktur Tbk, PT Citatah Tbk, and from other sectors. Other ten issuers were late in reporting their 2018 financial statements in 2019; among the ten companies, two were mining companies, namely PT Apexindo Pratama Duta Tbk, PT Energi Mega Persada Tbk, and the rest from other sectors. Thirty issuers were late in reporting their 2019 financial statements in 2020. Of these 30 companies, 11 were mining companies, namely PT Atlas Resources Tbk, PT Borneo Olah Sarana Sukses Tbk, PT Alfa Energi 
Investama Tbk, PT Garda Tujuh Buana Tbk, PT Resource Alam Indonesia Tbk, PT Apexindo Pratama Duta Tbk, PT Ratu Prabu Energi Tbk, PT Astrindo Nusantara Infrastruktur Tbk, PT Medco Energi Internasional Tbk, PT Citatah Tbk, PT J Resources Asia Pacific Tbk and the rest from other sectors.

From the results of previous studies regarding the impact of the age of the issuer on Audit Delay and the results obtained (Lienardi \& Widyaastuti, 2017); (Bahri, et al 2018); (Khamimah \& Kartikasari, 2019) and (Saputra et al 2020) stated that there is a significant impact of the age of the issuer on audit delay. Research on the effect of PAF Size has inconsistent results. According to Harjanto (2017), Lienardi \& Widyaastuti (2017) and Khamimah \& Kartikasari (2019) it is stated that Audit Delay is influenced by the PAF Size, in contrast to research (Bahri et al, 2018) it is noted that the Audit Delay is not affected by the PAF Size.

Then, research on audit delay influenced by the company's solvency obtained inconsistent results, an argument from Harjanto (2017) and (Lienardi \& Widyastuti, 2017) it is stated that Audit Delay is not affected by Company solvency. Meanwhile, argument from (Saputra et al, 2020) it is stated that Audit Delay is affected by the Company's Solvency.

Table 1. Research Gap

\begin{tabular}{cclc}
\hline Variables & \multicolumn{1}{c}{ Researcher } & Research result \\
\hline & - & Lienardi \& Widyaastuti (2017) & \\
Company Age & - & Bahri, et al (2018) & Significantly, Audit Delay is \\
& - & Khamimah \& Kartikasari (2019) & \\
& - & Saputra, et al (2020) & \\
\hline & - & Harjanto (2017) & \\
Public & - & Lienardi \& Widyaastuti (2017) & Audit delay is affected by PAF Size \\
Accounting & - & Khamimah \& Kartikasari (2019) & \\
Firm Size & - & Bahri et al (2018) & Audit Delay is not affected by Public \\
& & & Accounting Firm Size \\
\hline Company & - & Harjanto (2017) & There is an influence between \\
Solvency & - & Saputra, et al (2020) & Company Solvency on Audit Delay \\
& & & There is no influence between \\
& & Company Solvency on Audit Delay \\
\hline
\end{tabular}

Based on this background, it appears that there are several different research conclusions therefore it is necessary to research several factors of Company Age, Size of Public Accounting Firms and Company Solvency on audit delay.

\section{RESEARCH METHODS}

The study was carried out in mining companies listed on the Indonesia Stock Exchange (IDX) from 2017 to 2019. Samples were collected using purposive Sampling technique.

Table 2. Sample Selection Results

\begin{tabular}{llc}
\hline No. & \multicolumn{1}{c}{ Information } & Amount \\
\hline 1. & $\begin{array}{l}\text { Population: Mining Companies listed on the IDX for the } \\
\text { period 2017 to 2019 }\end{array}$ & 47 \\
\hline 2. & $\begin{array}{l}\text { Sample Criteria: } \\
\text { Mining companies listed on the IDX for 3 years, 2017 to 2019, } \\
\text { issue financial statements as of Dec 31. }\end{array}$ & 15 \\
\hline Total sample during the research period & 32 \\
\hline
\end{tabular}

Source: Data processed, 2021

The secondary data on mining companies listed on the Indonesia Stock Exchange (IDX) during 2017-2019.were obtained the data from www.idx.co.id. The data were analyzed using SPSS 21 software. The data analysis involved descriptive statistical analysis techniques, 
classical assumption testing (normality, multicollinearity, heteroscedasticity, autocorrelation), and multiple linear regression analysis. The coefficient of determination $\left(\mathrm{R}^{2}\right), \mathrm{t}$ statistical, and $\mathrm{F}$ test. Multiple linear equations used are as follows:

$\left.\mathrm{Y}=\mathrm{a}+\mathrm{b}_{1} \mathrm{X}_{1}+\mathrm{b}_{2} \mathrm{X}_{2}+\mathrm{b}_{3} \mathrm{X}_{3}-\varepsilon \ldots \ldots \ldots \ldots . \ldots 1\right)$

Notes :

\begin{tabular}{|c|c|}
\hline Y & $=$ Audit Delay \\
\hline $\mathrm{X}_{1}$ & $=$ Company Age \\
\hline $\mathrm{X}_{2}$ & $=$ PAF Size \\
\hline $\mathrm{X}_{3}$ & $=$ Firm Solvency \\
\hline $\mathrm{a}$ & $=$ Constant \\
\hline $\begin{array}{l}b_{1} b_{2} b_{3} \\
e^{-10}\end{array}$ & $\begin{array}{l}=\text { Regression coefficient } \\
=\text { Confounding variable }\end{array}$ \\
\hline
\end{tabular}

\section{RESULT AND DISCUSSION}

Result

Descriptive Statistical Analysis

Table 3. Descriptive Statistics Test Results

Descriptive Statistics

\begin{tabular}{lrrrrr}
\hline & $\mathrm{N}$ & \multicolumn{1}{c}{ Minimum } & Maximum & \multicolumn{1}{c}{ Mean } & \multicolumn{1}{c}{ Std. Deviation } \\
\hline Company Age & 96 & 5 & 69 & 26.7188 & 14.64507 \\
Public Accounting Firm & 96 & .00 & 1.00 & .7916 & .48384 \\
Size & & & & & \\
Company Solvency & 96 & 0.11 & 1.29 & .5347 & .23604 \\
Audit Delay & 96 & 45 & 180 & 88.8229 & 25.95989 \\
Valid N (listwise) & 96 & & & & \\
\hline Sour & & & & &
\end{tabular}

Source: Secondary data processed by SPSS (2021)

\section{Company Age}

The company's age was determined by the difference between the current date and the date it was founded or established. From the table above, the company age the highest (maximum) value obtained is 69.00 years. The lowest (minimum) value is 5.00 years with an average of 26.7188 years and a standard deviation of 14.64507 years. The company that has the age with the highest value is PT Bukit Asam Tbk. In contrast, the company that has the period with the lowest value is PT Alfa Energi Investama Tbk and PT Merdeka Copper Gold Tbk.

\section{Public Accountant Firm (PAF) Size}

PAF Size in the research is divided into 2, namely PAF, The Big Four and PAF non The Big Four. The results of the descriptive analysis of the PAF Size variable obtained an average value of 0.7916 and a standard deviation of 0.48384 .

Table 4. Descriptive Statistic (PAF Size)

\begin{tabular}{lcc}
\hline \multicolumn{1}{c}{ Information } & Amount & Percentage (\%) \\
\hline PAF Big Four & 76 & $79 \%$ \\
PAF Non Big Four & 20 & $21 \%$ \\
Total & 96 & $100 \%$ \\
\hline
\end{tabular}

Source: Processed data (2021)

\section{Company Solvency}

Corporate Solvency is the ability of a company to meet all of its financial obligations when the company is liquidated. The solvency of the company in this study was measured using 
the debt to asset ratio. The results of the descriptive analysis of the Company's Solvency obtained the highest value of 1.29 and the lowest value of 0.11 with an average value of 0.5347 and a standard deviation of 0.23604 . The company with the highest corporate solvency value is PT Apexindo Pratama Duta Tbk, while the company with the lowest corporate solvency value is PT Harum Energy Tbk.

\section{Audit Delay}

The period for the completion of the audit which is calculated from the closing of the financial year to the date the audited report is published, is called the Audit Delay. As shown in the table, the audit delay is worth 45.00 days to 180.00 days, the average value is 88.8229 days and the standard deviation is 25.95989 . It can be seen that the average value of the audit delay of issuers in the sample is below 120 calendar days, which is a time requirement given by BAPEPAM in the submission of financial reports, which is within 120 days to BAPEPAM. The longest audit delay or with the highest value (maximum) of 180 days is PT Citatah Tbk, while the fastest audit delay or the lowest value (minimum) of 45 days is PT Elnusa Tbk.

\section{Classic assumption test Normality test}

Normality test aims to determine whether the data is normally distributed or not. Normality of data is important because with normally distributed data, the data is considered to represent the population. Normality testing in this study using One-Sample KolmogorovSmirnov. It is enough to read the significance value (asymp. Sig 2-tailed) (Priyatno, 2018:77). The decision making of normal data or not is as follows:

a) If $\mathrm{Sig}>0.05$ then the data is normally distributed

b) If Sig $<0.05$ then the data is not normally distributed

Normality test using One-Sample Kolmogrov-Smirnov. Normality testing can be seen in table 5 below:

Table 5. Normality Test Results One-Sample Kolmogorov-Smirnov Test

\begin{tabular}{llc}
\hline \multirow{2}{*}{$\mathrm{N}$} & & \multicolumn{1}{c}{$\begin{array}{c}\text { Unstandardized } \\
\text { Residual }\end{array}$} \\
\hline \multirow{2}{*}{ Normal Parameters ${ }^{\mathrm{a}, \mathrm{b}}$} & Mean & 96 \\
\cline { 2 - 3 } & Std. Deviation & \multicolumn{1}{c}{.123} \\
\hline \multirow{2}{*}{ Most Extreme Differences } & Absolute & .123 \\
\cline { 2 - 3 } & Positive & -.068 \\
\cline { 2 - 3 } & Negative & 1.205 \\
\hline Kolmogorov-Smirnov Z & & .109 \\
\hline Asymp. Sig. (2-tailed) & & \\
\hline
\end{tabular}

a. Test distribution is Normal.

b. Calculated from data

Source:Data processed by SPSS, 2021

From the Kolmogorov-Smirnov One-Sample test above, the significance value of the independent variable is 0.109 . it is concluded that if the sample data is under the criteria, it is normally distributed, then it has a sig value of more than 0.05 .

\section{Multicollinearity Test}

Based on the above results, from the multicollinearity test, it can be seen that the Tolerance value of the firm age variable is $0.859>10 \%$ and the VIF is $1.164<10$, which means that multicollinearity does not occur. The Tolerance value of the PAF Sizevariable is $0.827>$ 
$10 \%$ and the VIF is $1.209<10$, this means that multicollinearity does not occur. Meanwhile, the Tolerance value of the Company's Solvency is $0.913<10 \%$ and the VIF is $1.095<10$, which means that multicollinearity does not occur.

Table 6. Multicollinearity Test Results

Coefficients $^{\mathrm{a}}$

\begin{tabular}{llcl}
\hline & \multicolumn{3}{c}{ Collinearity Statistics } \\
\cline { 2 - 4 } Model & \multicolumn{2}{c}{ Tolerance } & VIF \\
\hline 1 & \multicolumn{1}{c}{ Company Age } &, 859 & 1,164 \\
\cline { 2 - 4 } Public Accounting Firm Size &, 827 & 1,209 \\
\hline \multicolumn{2}{l}{ Company Solvency } &, 913 & 1,095 \\
\hline
\end{tabular}

a. Dependent Variable: Audit Delay

Source: Data processed by SPSS, 2021

Thus, it can be said that the company's age, the PAF size, and the company's solvency are independent variables where multicollinearity does not occur among them in the regression model.

\section{Heteroscedasticity Test}

Heteroscedasticity is a condition wherein the regression model there is an inequality of variance from the residuals from one observation to another (Priyatno, 2018: 136). The test uses a significance level of 0.05 with a 2 -sided test, if the correlation between the independent variables and the residuals is obtained sig $>0.05$, it can be said that there is no heteroscedasticity problem. The heteroscedasticity test can be seen in Table below:

Table 7. Heteroscedasticity Test Results Correlations

\begin{tabular}{llr}
\hline & & Unstandardized Residual \\
\hline Company Age & Correlation Coefficient &,- 032 \\
\cline { 2 - 3 } & Sig. (2-tailed) &, 757 \\
\cline { 2 - 3 } & $\mathrm{N}$ & 96 \\
\hline Public Accounting Firm & Correlation Coefficient &, 062 \\
\cline { 2 - 3 } Size & Sig. (2-tailed) &, 548 \\
\cline { 2 - 3 } & $\mathrm{N}$ & 96 \\
\hline Company Solvency & Correlation Coefficient &,- 060 \\
\cline { 2 - 3 } & Sig. (2-tailed) &, 559 \\
\cline { 2 - 3 } & $\mathrm{N}$ & 96 \\
\hline
\end{tabular}

Source: Data processed by SPSS, 2021

It is known that the significance of the age of the company is 0.757 , the significance of the PAF Size is 0.548 , and the significance of the firm's solvency is 0.559 . Significance value of the variables of Firm Age, PAF Size and Firm Solvency is greater than the 0.05 significance level. This means that in the regression model, heteroscedasticity does not occur.

\section{Autocorrelation Test}

The test method uses the Durbin-Waston test (DW-Test) (Priyatno, 2018:144). Decision making on the Durbin Watson test is as follows:

a) DU < DW < 4-DU Then Ho is accepted, meaning that there is no autocorrelation.

b) DW $<$ DL or DW $>4$-DL then Ho is rejected, meaning an autocorrelation.

c) $\mathrm{DL}<\mathrm{DW}<\mathrm{DU}$ or 4 -DU $<\mathrm{DW}<4$-DL, meaning that there is no certainty or definite conclusion. The autocorrelation test can be seen in Table 8 below: 
Table 8. Autocorrelation Test Results Model Summary ${ }^{\mathrm{b}}$

\begin{tabular}{llllll}
\hline Model & $\mathrm{R}$ & R Square & $\begin{array}{l}\text { Adjusted R } \\
\text { Square }\end{array}$ & $\begin{array}{l}\text { Std. Error of the } \\
\text { Estimate }\end{array}$ & $\begin{array}{l}\text { Durbin- } \\
\text { Watson }\end{array}$ \\
\hline 1 &, $438^{\mathrm{a}}$ &, 192 &, 165 & 23,71866 & 1,757 \\
\hline
\end{tabular}

a. Predictors: (Constant), Firm Solvency, Firm Age, Public Accounting Firm Size

b. Dependent Variable: Audit Delay

Source: Data processed by SPSS, 2021

Durbin Watson's test results show that the value of 1.810 lies between du of 1.733 and 4-du's value of 2.267 , which means that there is no autocorrelation.

\section{Coefficient of Determination Test $\left(\mathbf{R}^{2}\right)$}

A multiple linear regression test is to find out the linear relationship between 2 or more independent variables with 1 dependent variable (Priyatno, 2018:107). The coefficient of Determination test can be seen in Table 9 below:

Table 9. Coefficient of Determination Test Results Model Summary ${ }^{b}$

\begin{tabular}{lcccc}
\hline Model & R & R Square & $\begin{array}{c}\text { Adjusted R } \\
\text { Square }\end{array}$ & $\begin{array}{c}\text { Std. Error of the } \\
\text { Estimate }\end{array}$ \\
\hline 1 &, $438^{\mathrm{a}}$ &, 192 & \multicolumn{1}{c}{, 165} & 23,71866 \\
\hline a. Predictors: (Constant), Firm Solvency, Firm Age, Public \\
Accounting Firm Size \\
b. Dependent Variable: Audit Delay \\
Source: Data processed by SPSS, 2021
\end{tabular}

The known coefficient of determination $\left(\mathrm{R}^{2}\right)$ is 0.165 or in percentage it is $16.5 \%$. This shows that the influence of the variable age of the company, the PAF Size on the audit delay is $16.5 \%$ while other variables or other factors influence the remaining $83.5 \%$.

T-test

Table 10. $t$ test results Coefficients $^{\mathrm{a}}$

\begin{tabular}{llllll}
\hline \multirow{3}{*}{ Model } & & \multicolumn{2}{l}{ Unstandardized Coefficients } & Standardized Coefficients & \\
\cline { 2 - 5 } & & $\mathrm{B}$ & Std. Error & Beta & $\mathrm{t}$ \\
\hline 1 & (Constant) & 71,864 & 12,705 & & 5,657 \\
\cline { 2 - 5 } & Company Age &, 211 &, 270 &, 080 & 2,733 \\
\cline { 2 - 5 } & Cap Size & $-21,335$ & 8,321 &,- 268 &, 786 \\
\cline { 2 - 5 } & $\begin{array}{l}\text { Company } \\
\text { Solvency }\end{array}$ & 44,373 & 16,237 &, 272 &, 780 \\
\hline
\end{tabular}

a. Dependent Variable: Audit Delay

Source: Data processed by SPSS, 2021

Company Age variable obtained a significant value of $0.008<0.05$. Meanwhile, based on the comparison, $t$ count obtained a value of 2,733 greater than $t$ table of 1,986 . Therefore, $\mathrm{H}_{1}$ is accepted and $\mathrm{H}_{0}$ is rejected. Thus, the Audit Delay is partially affected by the company's age. Variable PAF Size obtained a significant value of $0.012<0.05$. Meanwhile, based on the comparison, the t-count obtained a value of 2,564 greater than the t-table of 1,986. So, in this case, $\mathrm{H}_{2}$ is accepted, and $\mathrm{H}_{0}$ is rejected. So, the Audit Delay is partially influenced by the Public Accounting Firm (PAF).

The Firm's Solvency Variable obtained a significant value of $0.637>0.05$. Meanwhile, based on the comparison, $t$-count obtained a value of 0.780 smaller than t-table of 1.986 . So, in 
this case $\mathrm{H}_{0}$ is accepted and $\mathrm{H}_{3}$ is rejected., audit delay is partially not affected by the company's solvency.

F Test

The F-test or regression coefficient test is used together to find out whether the independent variables have a significant effect on the dependent variable (Priyatno, 2018: 137). Decision making is influential or not influential based on the following provisions: $\mathrm{H}_{0}$ is rejected If $\mathrm{F}$ count $>\mathrm{F}$ table, $\mathrm{H}_{0}$ is accepted If $\mathrm{F}$ count $<\mathrm{F}$ table, or decision making based on significance:

a) F sig $<0.05$ then $\mathrm{H}_{0}$ is rejected, meaning that the age of the company, the size of the public accounting firm and the firm's solvency simultaneously affect the audit delay.

b) F sig $>0.05$ then $\mathrm{H}_{0}$ is accepted, it means that the age of the company, the size of the public accounting firm and the firm's solvency simultaneously do not affect the audit delay. F-Test can be seen in table 11 below :

Table 11. F Test Results

\begin{tabular}{lcc}
\hline \multicolumn{1}{c}{ Variables } & F & Significant \\
\hline Company Age & & 7,267 \\
\cline { 1 - 1 } Public Accounting Firm Size & &, 000 \\
\cline { 1 - 2 } Company Solvency & &
\end{tabular}

The significance value of 0.000 is smaller than 0.05 . Meanwhile, based on the comparison of F-count and F-table, F-count obtained a value of 7.267 greater than the F-table of 2.70. So, the conclusion is that $\mathrm{H}_{4}$ is accepted, and $\mathrm{H} 0$ is rejected. It means that the Audit Delay is affected by the Age of the Company, PAF Size, and the Solvency of the Company simultaneously.

\section{Discussion}

\section{The Effect of Company Age on Audit Delay}

From the $\mathrm{T}$ test results, the significance value between Company Age and Audit Delay is $0.008<0.05$, then $\mathrm{t}$ count is 2.733 and t table is 1.986 . When testing the hypothesis, it means $\mathrm{H}_{1}$ was accepted and $\mathrm{H}_{0}$ was rejected. This means that Audit Delay is partially affected by Company Age.

So the audit delays occur in companies that have a longer age or operate earlier, on the contrary, audit delays are longer in companies that are just operating. This is because, companies that have an older age or start their operations earlier will have more experience in their internal control system, so that the company is well controlled. Companies that have an older age certainly have mature expertise in the process of collecting, recording and producing information that supports the audit process to be more effective and efficient. Thus, the auditor does not need a long time in auditing and is able to minimize errors when presenting financial statements.

Results are in line with the results of (Lienardi \& Widyastuti, 2017) from the results of the research it is concluded that companies that have been around for a long time will have more experience so that their internal control system becomes better. The older the company, the more ability to collect, process, and produce the information needed by the auditor to support the audit process more effectively and efficiently so that the audit time can be faster. This result is in line with research conducted by (Bahri, et al 2018), (Khamimah \& Kartikasari, 2019) and (Saputra, et al 2020) which states that company age has a significant effect on audit delay. 


\section{Effect of PAF Size on Audit Delay}

The results of the T test show that the significance value between PAF Sizeand Audit Delay is $0.012<0.05$. Then tcount obtained a value of 2,564 and ttable of 1,986 . Following the hypothesis testing, it is concluded that $\mathrm{H}_{2}$ is accepted and $\mathrm{H}_{0}$ is rejected. This means that there is a partial effect of PAF Size on Audit Delay. Then the conclusion is that the Auditor with a good reputation (PAF Big Four) will provide high quality, effective and efficient financial statement audit work in the completion of the audit work on time compared to the work of auditors from other Public Accounting Firms that are not included in the category (PAF Big Four). Faster or timely completion of audits is also a way for the PAF Big Four to maintain their reputation. This result agrees with the result of (Harjanto, 2017) from the research results, it is concluded that PAFs affiliated with the Big Four have high efficiency and competent resources to shorten audit delay. This result aligns with research conducted by (Lienardi \& Widyaastuti, 2017) and (Khamimah \& Kartikasari, 2019).

\section{The Influence of Company Solvency on Audit Delay}

T-test results show that the significance value of the Company's Solvency to Audit Delay is $0.637>0.05$. Then $\mathrm{T}$-count obtained a value of 0.780 and ttable of 1.986 . From the hypothesis test, it can be concluded that $\mathrm{H}_{0}$ is accepted and $\mathrm{H}_{3}$ is rejected. This means that Company Solvency has no partial effect on Audit Delay. So, it can be concluded that the company's ability to pay all its debts when dissolved or liquidated does not affect Audit Delay. This is because auditors have the same standards in audit procedures for companies that have small total debt and companies that have large total debts, this is regulated under the Professional Standards of Public Accountants (SPAP) in carrying out their work. The results of this research are very supportive and in line with the research that has been carried out by (Harjanto, 2017) from the results of the research it is concluded that the high level of debt owned by the company does not guarantee that the company has an obligation to submit financial statements for a longer time than companies with high levels of debt. lower debt because it returns to the company's performance in maintaining its reputation to creditors. This result is in line with research conducted by (Lienardi \& Widyaastuti, 2017).

\section{Effect of Company Size, Audit Opinion, and Operating Profit on Audit Delay}

After the F-test, the independent variable obtained a significance value of $0.000<0.05$. Meanwhile, based on the comparison of Fcount and F-table, F-count obtained a value of 7.267 greater than F-table of 2.70. So, it can be concluded that $\mathrm{H}_{4}$ is accepted and $\mathrm{H}_{0}$ is rejected. This means that there is an influence of the company's age, the PAF Size and the solvency of the company having a simultaneous effect on the audit delay. So, the conclusion is that the age of the issuer, the PAF Size and the solvency of the issuer together have an impact on audit delay. The result of the research is the $\mathrm{R}$ square value of 0.165 / presented $16.5 \%$ which means that together the age of the issuer, the size of the PAF and the solvency of the issuer have an impact on audit delay as much as $16.5 \%$ while the remaining $83.5 \%$ are other variables or other factors. that is not in the research that influences it.

\section{CONCLUSIONS AND SUGGESTIONS}

From the results of the analysis and discussion, the following conclusions are drawn Audit Delay is affected by Company Age, Audit Delay is affected by the PAF Size, Audit Delay is not affected by Company Solvency, and There is an effect of Company Age, size of The Public Accounting Firm (PAF) and firm solvency on Audit Delay. Mining companies listed on the IDX to maintain the factors that affect Audit Delay, namely Company Age, so that Audit Delay can be reduced to a minimum and audited financial statements can be published on time. On the factor of Public Accountant Size that affects Audit Delay, it is recommended to Mining 
Companies listed on the Indonesia Stock Exchange (IDX) to be able to maintain this factor so that Audit Delay can be suppressed and be able to publish audited financial statements on time. The Company's Solvency factor does not affect Audit Delay, it is recommended to Mining Companies listed on the Indonesia Stock Exchange (IDX) to improve this factor further so that Audit Delay can be minimized and can publish audited financial statements promptly. Mining companies listed on the Indonesia Stock Exchange (IDX) must continue to work professionally and conduct periodic assessments of each other's performance to control the main factors that affect Audit Delay. From the results of this study, the firm's age, the PAF Size and the firm's solvency simultaneously affect the audit delay. In addition, the company must be able to provide complete data needed by the auditor so that it does not cause delay in the issuance of audit reports that can cause audit delays for the company.

\section{REFERENCE}

Amani, Fauziyah Althaf, and Indarto Waluyo. (2016). Pengaruh Ukuran Perusahaan, Profitabilitas, Opini Audit, Dan Umur Perusahaan Terhadap Audit Delay (Studi Empiris Pada Perusahaan Property Dan Real Estate Yang Terdaftar Di Bursa Efek Indonesia Pada Tahun 2012-2014). Nominal, Barometer Riset Akuntansi Dan Manajemen, 5.1 (135-150), https://doi.org/10.21831/nominal.v5i1.11482>

Apriyana, Nurahman, and Diana Rahmawati. (2017). Pengaruh Profitabilitas, Solvabilitas, Ukuran Perusahaan, Dan Ukuran PAF Terhadap Audit Delay Pada Perusahaan Properti Dan Real Estate Yang Terdaftar Di Bursa Efek Indonesia Periode 2013-2015. Nominal, Barometer Riset Akuntansi Dan Manajemen, 6(2), 108-124, https://doi.org/10.21831/nominal.v6i2.16653.

Charviena, Charviena, and Elis Tjhoa. (2016). Pengaruh Ukuran Perusahaan, Laba Rugi Operasi, Solvabilitas, Umur Perusahaan, Klasifikasi Industri, Dan Ukuran KAP Terhadap Audit Delay. Ultimaccounting: Jurnal Ilmu Akuntansi, 8.2 66-88, https://doi.org/10.31937/akuntansi.v8i2.582.

Clarisa, Saskya., Pangerapan, Sonny. (2019). Pengaruh Ukuran Perusahaan, Solvabilitas, Profitabilitas, Dan Ukuran PAF Terhadap Audit Delay Pada Perusahaan Sektor Pertambangan Yang Terdaftar Di Bursa Efek Indonesia', Jurnal EMBA: Jurnal Riset Ekonomi, Manajemen, Bisnis Dan Akuntansi, 7(3), 3069-3078, https://doi.org/10.35794/emba.v7i3.24060.

Dewi, Maya Widyana. Kristiyanti LMS. (2020). Pengaruh Ukuran Perusahaan, Solvabilitas, Laba Rugi Dan Umur Perusahaan Terhadap Audit Delay. Proceeding Seminar Nasional \& Call For Papers, November 2020, 116-27

Harjanto, Karina. (2018). Pengaruh Ukuran Perusahaan, Profitabilitas, Solvabilitas, Dan Ukuran Kantor Akuntan Publik Terhadap Audit Delay', Jurnal ULTIMA Accounting, 9(2), 33-49, https://doi.org/10.31937/akuntansi.v9i2.728.

Khamimah. (2019). The Effect of Company'S Size, Company'S Age, Profitability, Solvibility and Audit Firm Size on the Audit Delay in Lq 45 Company Listed on the Indonesia Stock Exchange in 2015-2017, Journal of Physics A: Mathesmatical and Theoretical, 44(8) 276.

Lienardi, Vega, and Theresia Dian Widyastuti. (2017). Analisis Pengaruh Persentase Kepemilikan Asing, Latar Belakang Pendidikan Komite Audit, Ukuran KAP, Umur Perusahaan, Profitabilitas, Dan Solvabilitas Terhadap Audit Delay (Studi Empiris 
Perusahaan Pertambangan Yang Tercatat Pada Bursa Efek Indonesia Period. Balance, 14.2, 196-226.

Patinaja, Elna Marsye., Siahainenia, Pieter Prima. (2020). Pengaruh Ukuran Perusahaan, Opini Auditor Dan Umur Perusahaan Terhadap Audit Delay. Journal of Physics A: Mathematical and Theoretical, 44(8), 13-22.

Saputra, Alan Darma, Chalisa Rahmi Irawan, and Wenny Anggresia Ginting. (2020). Pengaruh Ukuran Perusahaan, Opini Audit, Umur Perusahaan, Profitabilitas Dan Solvabilitas Terhadap Audit Delay. Owner (Riset Dan Jurnal Akuntansi), 4(2) 286-295, 10.33395/owner.v4i2.239

Saragih, Muhammad Rizal. (2019). The Effect of Company Size, Solvency, and Audit Committee on Delay Audit', Scientific Journal of Reflection: Economic, Accounting, Management and Business, 2(2) 191-200, https://doi.org/10.5281/zenodo.2628084.

Sayidah, Nur. (2019). Pengaruh Ukuran Perusahaan, Profitabilitas, Solvabilitas Dan Opini Auditor Terhadap Audit Delay', Jurnal Analisa Akuntansi Dan Perpajakan, 2(2), https://doi.org/10.25139/jaap.v2i2.1397.

Sugiyono. (2012). Metode Riset Bisnis. Bandung. Cv. Alfabeta.

Sugiyono. (2019). Metode Riset Kuantitatif, Kualitatif, Dan R\&D. Bandung: Cv. Alfabeta.

Widiastuti, Ika Destriana, and Andi Kartika. (2018). Ukuran Perusahaan, Profitabilitas, Umur Perusahaan, Solvabilitas Dan Ukuran PAF Terhadap Audit Report Lag', Dinamika Akuntansi, Keuangan Dan Perbankan, 7(1), 20-34, https://www.unisbank.ac.id/ojs/index.php/fe9/article/view/7443.

Witjaksono, Armanto, and Mega Silvia. (2017) Analisis Faktor-Faktor Yang Berpengaruh Terhadap Audit Delay Pada Perusahaan Mining Dan Infrastructure. Jurnal Akuntansi, 6(1), 32-46. 